\title{
New CAR shopping
}

\section{By Steve Edelson, Executive Editor of New Media}

With two papers in the literature this week solidifying the efficacy of CD19-based chimeric antigen receptor T cells, the question now is how many other targets are amenable to the approach. Target selection is among the most challenging tasks in the chimeric antigen receptor space and was a hotly discussed topic at last year's SciBX Summit on Innovation in Drug Discovery and Development. ${ }^{1}$

This week, Kite Pharma Inc. announced the publication in Lancet of results from a Phase I trial of KTE-C19 to treat relapsed/ refractory acute lymphoblastic leukemia (ALL). ${ }^{2}$ In the 20-patient study, 14 (70\%) had a complete response. Of the responders, 12 had no evidence of minimal residual disease.

"With CARs and TCRs you
have a knife that is so sharp
that you have to be sure
the target does not express
anywhere else outside the
cancer itself."
-Arie Belldegrun, Kite Pharma Inc.

$A B$ : You have to find targets that are not just highly expressed but are $100 \%$ expressed on tumors and not expressed on any normal tissue. With CARs and T cell receptors you have a knife that is so sharp that you have to be sure the target does not express anywhere else outside the cancer itself.

With vaccines you can get away with low levels of expression on normal tissue because the vaccine is not as sharp. And that's why you don't see cancer melting away. But CARs and T cell receptors are really a major killer and don't differentiate between a good cell and bad cell. The CAR T cell looks outside and if it sees an antenna, it's a killer for hire. It doesn't make any difference what the cell of origin is or where it is located-and therefore the target is critical. SciBX: One idea that was put forward at last year's SciBX Summit was to pursue targets that were uncovered during decades of $\mathrm{mAb}$ development as those targets should have a healthy amount of underlying validation.

$A B$ : Other companies have worked on EGFRvIII as a target for antibodies. They didn't have a CAR in mind at all, but now suddenly it's an
The study was run by the National Cancer Institute, which has a cooperative $R \& D$ agreement (CRADA) with Kite to develop chimeric antigen receptor (CAR) and T cell receptor (TCR) products.

Also this week, researchers from the University of Pennsylvania and partner Novartis AG published in The New England Journal of Medicine results from a Phase I/IIa study of their CTL019 to treat relapsed/ refractory ALL. ${ }^{3}$ In the 30-patient trial, there were 27 complete responses (90\%). At 6 months, the event-free survival rate was $67 \%$ and the overall survival rate was $78 \%$.

In both cases, the results are way ahead of previous approaches, given that chemotherapy regimens for relapsed/refractory ALL generally have complete response rates below $25 \%$.

SciBX recently sat down with Arie Belldegrun, president and CEO of Kite, to discuss how his company is thinking about target selection for CAR T cells. He believes finding targets is both the most important and the most difficult aspect of early stage CAR T cell research.

Belldegrun expects the most fertile ground for target discovery will be where antibody companies have looked in the past. What those targets may sacrifice in sheer novelty will be more than compensated for by the availability of information about their safety.

The conversation with Belldegrun follows.

SciBX: In addition to KTE-C19, Kite has a CAR T cell therapy against epidermal growth factor variant III (EGFRvIII) that is in Phase I testing to treat glioblastoma. How do you arrive at your next compound after that?

Arie Belldegrun: The bottleneck today in the development of CAR and TCR technology is finding targets. This is the most important future research project at any company. example of a very important selective target. So that's where things will move in the future and that's where many CAR targets will come from.

It's how we have started assembling our different genes-the NY-ESO-1 [cancer/testis antigen 1B (CTAG1B)] T cell receptor, the MAGE [melanoma-associated antigen] $\mathrm{T}$ cell receptor, the SSX2 [synovial sarcoma X breakpoint 2] T cell receptor. This is a major effort that we are working on right now. A key for us is finding collaborations with companies that have significant experience with target discoverypossibly coming from the antibody days.

As a matter of fact at Agensys Inc. in 1996 we had multiple antibody targets that we discovered that are now in the hands of Astellas Pharma Inc. I wish at that time we could have foreseen what was coming and kept some of these targets that we just gave away.

SciBX: Like you said, a lot of companies are going to have a basement full of interesting antibody targets that could become strong CAR T targets. But how far off are we from brand new targets? Is that going to happen or will it only be after we've exploited the antibody targets?

$A B$ : 'Brand new' means a lot of research to make sure it's really target specific. The new discoveries that you are talking about are hugely expensive to validate that the target isn't expressed in any other tissue. So first you will probably take every possible tissue in the body in biopsies and you'll do staining. And after that you probably will start very cautiously-FDA will have you dose your drug almost like water and then increase very slowly.

So to answer you: it will happen, but it takes a little bit of time. The genie is out of the box-I can see the proliferation of potential targets growing very rapidly. 


\section{ANALYSIS}

\section{TRANSLATIONAL NOTES}

SciBX: Do you think in the research world that the technologies have been developed that can give the assuredness that your target is going to be exclusively expressed on a tumor? Or is that something that needs to come up to speed?

$A B$ : It is an extremely important question. So far I don't see a mechanism to be $100 \%$ secure with new CAR and TCR technologies. In the future you can see potentially doing something like a genetic PET scanning, but it's not developed yet.

SciBX: So do you think safety switches like suicide genes will be the de facto standard for any new CARs?

$A B$ : With CD19 we brought it up for discussion internally and with the National Cancer Institute several times. And we got to the conclusion that we do not need such a safety mechanism because we have treated so many patients and that we do not need this mechanism to secure us. For other genes, if it's possible and it is simple, I don't see a problem with a safety mechanism. Obviously now you are introducing one gene and another gene and you didn't yet approve the first gene, so there are regulatory issues.

SciBX: Thank you for your time.

Edelson, S. SciBX 7(40); doi:10.1038/scibx.2014.1169

Published online Oct. 16, 2014

REFERENCES

1. Baas, T. SciBX 7(25); doi:10.1038/scibx.2014.725

2. Amrolia, P.J. \& Pule, M. Lancet; published online Oct. 13, 2014; doi:10.1016/S0140-6736(14)61729-3

3. Maude, S.L. et al. N. Engl. J. Med. 371, 1507-1517 (2014)

COMPANIES AND INSTITUTIONS MENTIONED

Astellas Pharma Inc. (Tokyo:4503), Tokyo, Japan

Kite Pharma Inc. (NASDAQ:KITE), Los Angeles, Calif.

National Cancer Institute, Bethesda, Md.

Novartis AG (NYSE:NVS; SIX:NOVN), Basel, Switzerland

University of Pennsylvania, Philadelphia, Pa. 